\title{
Alpha-fetoprotein, alpha-1-antitrypsin, and transferrin in gonadal yolk-sac tumours
}

\author{
J. O. W. BEILBY, C. H. W. HORNE, G. D. MILNE,
} AND CONSTANCE PARKINSON

From the Bland-Sutton Institute of Pathology, The Middlesex Hospital Medical School, London WI, the Department of Histopathology, University of Aberdeen, and Guy's Hospital Medical School, London, UK

SUMMARY Since gonadal yolk-sac tumour in pure form or as a component of mixed germ cell tumour is in the majority of patients highly malignant, its histological recognition is of great prognostic importance. Yolk-sac tumour may assume various different histological guises, which have hitherto caused considerable terminological confusion; the present paper is aimed at correlating these morphological diversities with biochemical features which are consistent with yolk-sac differentiation. Using an enzyme-bridge immunoperoxidase technique, a series of 16 gonadal germ cell tumours with a yolk-sac component were screened for the presence of alpha-fetoprotein, alpha-1-antitrypsin, and transferrin. These proteins, normally produced by human yolk sac, were demonstrable in all the morphological patterns of yolk-sac tumour we have previously described. Six malignant non-germ cell tumours were submitted to the same investigations, and no evidence of the three protein markers was found in five; one tumour, however, an oat cell carcinoma of the bronchus, stained positively for transferrin.

Raised serum levels of alpha-fetoprotein (AFP) have been identified in patients with certain germ cell tumours (Abelev et al., 1967; Masopust et al., 1968; Hull et al., 1969; Smith and O'Neill, 1971; Tsuchida et al., 1973; Wilkinson et al., 1973; Abelev et al., 1974; Talerman and Haije, 1974; Kohn et al., 1976; Lie-Injo et al., 1976; Neville et al., 1976; Grigor et al., 1977). In 1970, Gitlin and Pericelli demonstrated, among other proteins, AFP, $\alpha_{1}$-antitrypsin $\left(\mathrm{A}_{1} \mathrm{AT}\right)$, and transferrin production by normal human yolk sac in tissue culture. In view of these findings, it seemed logical to assume that the raised serum AFP in patients with germ cell neoplasms was explained by the presence of yolk-sac tumour (Wilkinson et al., 1973; Abelev et al., 1974; Talerman and Haije, 1974; Teilum et al., 1975; Kohn et al., 1976; Neville et al., 1976; Grigor et al., 1977; Talerman et al., 1978). Nørgaard-Pedersen et al. (1975), using an immunofluorescent technique, demonstrated AFP in the cells lining the endodermal sinuses and the hyaline globules of three yolk-sac neoplasms. Palmer et al. (1976) and Palmer and Wolfe (1978) identified AFP and $A_{1}$ AT similarly distributed in a further five yolk-sac neoplasms by

Received for publication 10 October 1978 indirect immunofluorescent and immunoperoxidase techniques.

Using AFP as a serum marker for yolk-sac tumour, it appeared that this neoplasm occurred more frequently in the adult testis than is indicated by either of the major histological classifications of testicular tumours currently in use (Mostofi and Price, 1973; Pugh, 1976). Talerman and Haije (1974), in a retrospective histological study of germ cell neoplasms, found a close correlation between yolksac tumour and raised levels of serum AFP in six out of 24 clinically active testicular neoplasms. Neville et al. (1976) reviewed the histology of their cases of testicular 'teratomata' and showed a close relationship between yolk-sac tumour foci and raised AFP levels in the serum of two-thirds of these patients. In a retrospective morphological study of 92 testicular tumours, previously reported as teratomata, Parkinson and Beilby (1977) found 33 pure yolk-sac neoplasms and 49 mixed germ cell tumours which contained yolk-sac elements.

The wide discrepancy in the reported incidence of yolk-sac tumour in the adult testis may be explained by the failure to appreciate the spectrum of morphological patterns found in this neoplasm. This contention is supported by Neville et al. (1976), who 
observed that typical yolk-sac patterns merged with undifferentiated areas in which the component cells formed sheets or cords. They suggested that these patterns might represent a form of yolk-sac tumour. Similarly, Kurman et al. (1977) demonstrated AFP in the mononuclear cells of 'embryonal carcinoma, adult type', in addition to the Duval-Schiller bodies and microcystic foci of classical yolk-sac tumour.

Morphological recognition of yolk-sac tumour is important because it indicates a poor prognosis (Beilby and Parkinson, 1975; Parkinson and Beilby, 1977). We have previously described and illustrated the morphological patterns we consider to be indicative of yolk-sac differentiation in ovarian (Beilby and Parkinson, 1975) and testicular (Parkinson and Beilby, 1977) neoplasms. The same range of tumour patterns has been investigated to see if they are associated with the biochemical characteristics of human yolk-sac, that is, AFP, A1AT, and transferrin synthesis.

\section{Material and methods}

Six ovarian and 10 testicular germ cell tumours previously diagnosed as pure yolk-sac neoplasms or mixed germ cell tumours with a yolk-sac component were selected from the records of the Middlesex Hospital. Haematoxylin and eosin stained sections of each tumour were examined, and the morphological patterns of yolk-sac tumour, that is, Duval-Schiller bodies, microcystic or reticular, solid nodular, and acinopapillary listed. In mixed germ cell tumours the non yolk-sac element was recorded.

Six malignant non-germ cell tumours from bronchus, breast, and stomach were included in the study as controls to investigate the specificity of AFP, $\mathrm{A}_{1} \mathrm{AT}$, and transferrin as yolk-sac tumour markers.

\section{IMMUNOPEROXIDASE TECHNIQUE}

Five-micron sections were cut from paraffinembedded blocks of tissue which had previously been fixed in formol saline.

The method was that described by Heyderman and Munro Neville (1977). After taking the sections to water endogenous peroxidase was partially blocked by treating sections with $0.1 \mathrm{~m}$ periodic acid for 5 minutes and with $0.02 \%$ sodium borohydride for 2 minutes. Non-specific background staining was reduced by using normal swine serum diluted 1 in 10 with $1 \%$ bovine serum albumin in saline for 5 minutes. The sections were then treated with the specific antisera for $\mathbf{3 0}$ minutes. Swine anti-rabbit immunoglobulin serum was then applied followed by peroxidase-antiperoxidase complex. Sites of peroxidase activity were demonstrated using the diamino-benzidine reaction. Washing between each step was carried out in PBS, pH 7.4, containing a few drops of detergent.

Antisera to AFP (Behring) when tested against normal human fetal plasma, and $\mathrm{A}_{1} \mathrm{AT}$ and transferrin (Dakopatts) when similarly tested against normal human plasma, were shown to give a single precipitin line on immunoelectrophoresis. All antisera were used throughout at a dilution of 1 in 30, swine antirabbit immunoglobulin (Dakopatts) at a dilution of 1 in 20, and peroxidase-antiperoxidase complex (PAP) (Dakopatts) at a dilution of 1 in 50. Since purified protein was not available for absorption studies, control sections for AFP were treated with diluted specific antisera which had been absorbed with freeze-dried fetal plasma, and for $A_{1}$ AT and transferrin with specific antiserum absorbed with freeze-dried normal human plasma. Although these materials contained appreciable quantities of the appropriate protein, in the absence of purified antigen it is impossible to exclude the possibility that absorption of cross-reacting antigens (not detected on immunoelectrophoresis) may also have taken place.

Each section was examined in conjunction with its control. The reaction was recorded as positive only in the presence of a negative reaction in a similar morphological area in the control section. The density of staining and the association of a positive reaction with any particular morphological pattern were noted.

\section{Results}

The Table relates the morphological and immunocytochemical findings in a series of 16 gonadal germ cell tumours. Figures 1 to 9 illustrate the distribution of the three marker proteins in some of the morphological variants showing yolk-sac differentiation.

Fourteen of the neoplasms showed at least two different histological patterns assumed by yolk-sac tumour, but in two instances (cases 14 and 15) only the acinopapillary component was present. Three neoplasms (cases 3,9 , and 13) incorporated mature somatic elements in addition to yolk-sac tumour.

In four of the six ovarian neoplasms, all three protein markers were present (cases $1,3,5$, and 6); two markers (AFP and transferrin) were seen in one instance (case 2), and transferrin alone was detected in case 4. Six of the 10 testicular tumours (cases 7, $9,12,13,14$, and 15) showed a positive reaction for all three marker proteins. In one neoplasm (case 8), AFP and $A_{1} A T$ gave positive reactions. In case 16, only $A_{1}$ AT was detected. Two testicular tumours (cases 10 and 11) proved negative for all three proteins. The intensity of the staining for each 
Table Morphological and immunocytochemical findings in gonadal yolk-sac tumours

\begin{tabular}{|c|c|c|c|c|c|c|c|c|c|}
\hline \multirow[t]{2}{*}{ Case } & \multirow{2}{*}{$\begin{array}{l}\text { Age } \\
(y r)\end{array}$} & \multirow[t]{2}{*}{ Site } & \multicolumn{4}{|c|}{ Yolk sac morphology } & \multirow[t]{2}{*}{$A F P$} & \multirow[t]{2}{*}{$A_{1} A T$} & \multirow[t]{2}{*}{ Transferrin } \\
\hline & & & $\begin{array}{l}\text { Duval-Schiller } \\
\text { bodies }\end{array}$ & $\begin{array}{l}\text { Microcystic } \\
\text { and reticular }\end{array}$ & $\begin{array}{l}\text { Solid } \\
\text { nodular }\end{array}$ & Acinopapillary & & & \\
\hline 1 & 11 & Ovary & - & + & + & - & + & + & + \\
\hline 2 & 15 & ", & + & + & + & - & + & - & + \\
\hline $3 *$ & 26 & ", & + & + & + & + & + & + & + \\
\hline 4 & 32 & ", & + & + & + & - & - & - & + \\
\hline 5 & 51 & ", & - & + & + & + & + & + & + \\
\hline 6 & 59 & ", & - & - & + & + & + & + & + \\
\hline 7 & 4 & Testis & - & + & + & - & + & + & + \\
\hline 8 & 20 & , & + & + & + & - & + & + & - \\
\hline $9^{*}$ & 21 & ," & - & + & - & + & + & + & + \\
\hline 10 & 26 & ", & + & + & - & + & - & - & - \\
\hline 11 & 26 & ," & + & - & - & + & - & - & - \\
\hline 12 & 30 & ", & + & + & + & - & + & + & + \\
\hline $13^{*}$ & 36 & ", & - & - & + & + & + & + & + \\
\hline 14 & 37 & ", & - & - & - & + & + & + & + \\
\hline 15 & 39 & ", & - & - & - & + & + & + & + \\
\hline 16 & 40 & ", & - & + & - & + & - & + & - \\
\hline
\end{tabular}

*Mixed germ cell neoplasms composed of somatic elements and yolk-sac tumour.

protein varied from field to field within each neoplasm, and thus satisfactory grading of the reaction was impossible.

The localisation of all three marker proteins was patchy and unrelated to any specific morphological structure; positive reactions were seen in endothelial cells lining channels, Duval-Schiller bodies, and solid nodular epithelial and acinopapillary foci.

In two mixed germ cell neoplasms (cases 3 and 13), the squamous epithelium of the somatic component gave a positive reaction for $\mathrm{A}_{1} \mathrm{AT}$ and transferrin. In the third mixed germ cell neoplasm (case 9), immature somatic epithelial tubules showed positive staining with all three marker proteins.

Six control non-germ cell malignant tumours showed no evidence of AFP and $\mathrm{A}_{1} \mathrm{AT}$, but transferrin was detected in one, an oat cell carcinoma of the bronchus.

\section{Discussion}

Gonadal yolk-sac tumour, either in pure form or as part of a mixed germ cell neoplasm, is in most patients, with the possible exception of boys under 2 years, highly malignant (Huntington and Bullock, 1970; Pierce et al., 1970; Talerman, 1975; Kurman and Norris, 1976a and b), and its histological identification is of prime prognostic significance (Beilby and Parkinson, 1975; Parkinson and Beilby, 1977). The neoplastic patterns we consider to show yolk-sac differentiation have been described previously (Beilby and Todd, 1974; Beilby and Parkinson, 1975; Parkinson and Beilby, 1977); they include acinopapillary and solid nodular epithelial variants in addition to the classical Duval-Schiller bodies and microcystic/reticular patterns. The aim of the current investigation was to correlate the morphological diversities of yolk-sac tumour with those biochemical features consistent with yolk-sac differentiation. We found that AFP, $A_{1} \mathrm{AT}$, and transferrin, proteins produced by normal human yolk sac (Gitlin and Perricelli, 1970), were demonstrable in all the morphological variants we described. Of the 16 germ cell tumours, only two were negative for all three proteins. In any given yolk-sac tumour, positive staining was discernible throughout all the histological variants present. Surprisingly, in this series it was more common for all three proteins to be present in neoplasms showing acinopapillary, microcystic/reticular, and solid nodular patterns than in those incorporating classical Duval-Schiller bodies (see Table).

Other investigators (Grigor et al., 1977) have not always demonstrated elevated serum levels of AFP in every patient with a yolk-sac tumour; although such discrepancies reduce the diagnostic reliability of serum tumour markers, they do not detract from their use and importance in aiding tumour classification.

The production of AFP, A AT, and transferrin is a characteristic but not specific function of yolk-sac tissue; these proteins are also synthesised by fetal liver (Gitlin and Boesman, 1967; van Furth and Adinolfi, 1969), and transferrin has a wide distribution in normal adult human tissues (Mason and Taylor, 1978). However, within the context of mixed germ cell tumours, these proteins prove satisfactory markers of yolk-sac components. Occasionally, somatic tissues do stain positively, as in case 13 of our series, but in such instances distinction from 

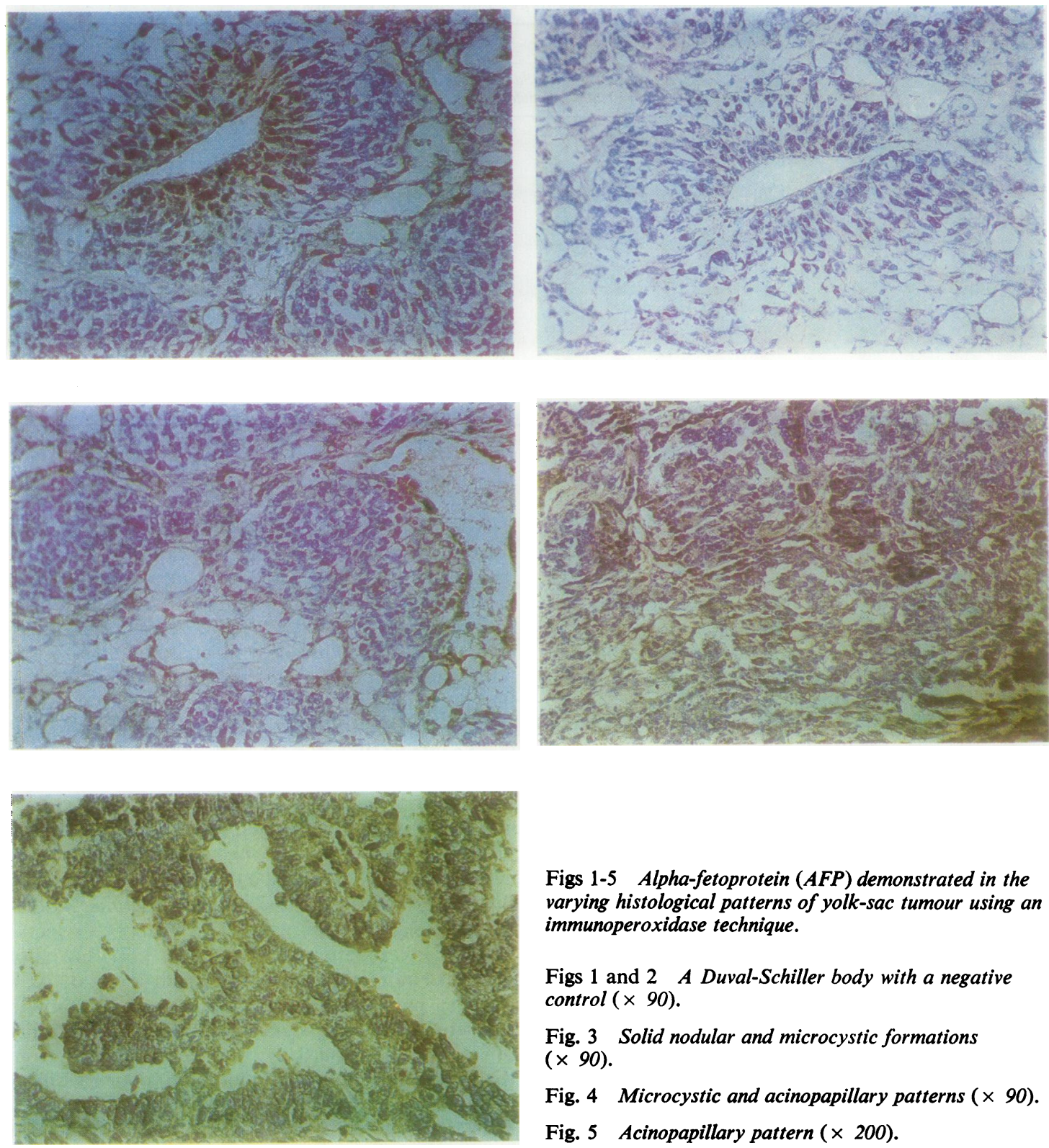

Figs 1-5 Alpha-fetoprotein (AFP) demonstrated in the varying histological patterns of yolk-sac tumour using an immunoperoxidase technique.

Figs 1 and 2 A Duval-Schiller body with a negative control $(\times 90)$.

Fig. 3 Solid nodular and microcystic formations $(\times 90)$.

Fig. 4 Microcystic and acinopapillary patterns $(\times 90)$.

Fig. 5 Acinopapillary pattern $(\times 200)$.

yolk-sac tumour is easily made on morphological grounds. Hepatic tissue, an obvious potential source of such proteins, is rarely seen in these germ cell tumours (Pugh and Cameron, 1976). In case 9, scattered immature tubules of gastrointestinal appearance stained positively for all three marker proteins, but these structures were readily distinguishable morphologically. The latter reaction may

be explained by the participation of yolk-sac endoderm in the development of the gastrointestinal tract, which may also be the reason for the reported occurrence of elevated levels of serum AFP in certain malignant gastrointestinal tumours (Mehlman et al., 1971; Akai and Kato, 1973; Adinolfi et al., 1975).

Grigor et al. (1977) suggested that AFP and inappropriate hormone secretion by malignant 



Figs 6-9 $A_{1} A T$ and transferrin distribution demonstrated by immunoperoxidase techniques.

Figs 6 and $7 \quad A_{1} A T$ in a microcystic pattern with a negative control $(\times 90)$.

Figs 8 and 9 Transferrin in reticular/microcystic pattern with a negative control $(\times 90)$.

tumours might be analogous processes, hence the location of such marker proteins in a germ cell tumour would not necessarily denote a vitelline differentiation; support for this contention, however, is slender. We found no evidence of the three protein markers in five of the six non-germinal malignant tumours we examined, although transferrin was demonstrable in one oat cell tumour of the bronchus. Lie-Injoe et al. (1976) examined sera from 330 patients with malignant tumours, and only 11 had elevated levels of serum AFP, four of whom had non-germ cell tumours. It might be significant, as reported by Tsung (1975), that in some disseminated non-germ cell neoplasms, AFP is not produced by the primary tumour but by liver cells adjacent to secondary hepatic deposits.

Kurman et al. (1977) have reported cellular localisation of AFP in 'embryonal carcinoma' in addition to 'endodermal sinus tumour' in testicular germ cell neoplasms. However, we do not regard these findings to be at variance with our own. Our views on the term 'embryonal carcinoma' have been expressed previously (Parkinson and Beilby, 1977); this nomenclature is confusing as many such neoplasms show undoubted yolk-sac differentiation and thus would be expected to synthesise AFP. We found that completely undifferentiated foci composed of sheets of pleomorphic cells were rare in testicular germ cell tumours (Parkinson and Beilby, 1977), and we have not had the opportunity to investigate protein markers in such cases.

Like Palmer and Wolfe (1978), therefore, we consider that the capacity of a germ cell tumour to elaborate oncofetal proteins not only supports the concept of a yolk-sac origin but also demonstrates the variety of histological patterns that these tumours may assume, thus helping with their classification and assisting with prognosis.

We thank Mrs Barbara Dickson for typing the manuscript. 


\section{References}

Abelev, G. I., Assecritova, I. V., Kraevsky, N. A., Perova, S. D., and Perevodchikova, N. I. (1967). Embryonal serum a-globulin in cancer patients: diagnostic value. International Journal of Cancer, 2, 551-558.

Abelev, G. I., Elgort, D. A., Perova, S. D. (1974). L'Alpha Foetoprotein, pp. 141-168. Inserm, Paris.

Adinolfi, A., Adinolfi, M., and Lessof, M. H. (1975). Alpha-feto-protein during development and in disease. Journal of Medical Genetics, 12, 138-151.

Akai, S., and Kato, K. (1973). Serum a-fetoproteinpositive stomach cancer. Gann Monographs on Cancer Research, 14, 149-154.

Beilby, J. O. W., and Parkinson, C. (1975). Features of prognostic significance in solid ovarian teratoma. Cancer, 36, 2147-2154.

Beilby, J. O. W., and Todd, P. J. (1974). Yolk sac tumour of the ovary. Journal of Obstetrics and Gynaecology of the British Commonwealth, 81, 90-94.

Gitlin, D., and Boesman, M. (1967). Sites of serum $a$-fetoprotein synthesis in the human and the rat. Journal of Clinical Investigation, 46, 1010-1016.

Gitlin, D., and Perricelli, A. (1970). Synthesis of serum albumin, prealbumin, a-foetoprotein, $a_{1}$-antitrypsin and transferrin by the human yolk sac. Nature, 228, 995-997.

Grigor, K. M., Detre, S. I., Kohn, J., and Neville, A. M.

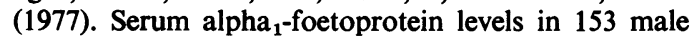
patients with germ cell tumours. British Journal of Cancer, 35, 52-58.

Heyderman, E., and Munro Neville, A. (1977). A shorter immunoperoxidase technique for the demonstration of carcinoembryonic antigen and other cell products. Journal of Clinical Pathology, 30, 138-140.

Hull, E. W., Moertel, C. G., and Carbone, P. P. (1969). Serum alpha fetoprotein in cancer patients (Abstract). Clinical Research, 17, 403.

Huntington, R. W., Jr., and Bullock, W. K. (1970). Yolk sac tumors of the ovary. Cancer, 25, 1357-1367.

Kohn, J., Orr, A. H., McElwain, T. J., Bentall, M., Peckham, M. J. (1976). Serum-alpha ${ }_{1}$-fetoprotein in patients with testicular tumours. Lancet, 2, 433-436.

Kurman, R. J., and Norris, H. J. (1976a). Malignant mixed germ cell tumors of the ovary. Obstetrics and Gynecology, 48, 579-589.

Kurman, R. J., and Norris, H. J. (1976b). Endodermal sinus tumor of the ovary. Cancer, 38, 2404-2419. urman, R. J., Scardino, P. T., McIntire, K. R., Waldmann, T. A., and Javadpour, N. (1977). Cellular localization of alpha-fetoprotein and human chorionic gonadotropin in germ cell tumors of the testis using an indirect immunoperoxidase technique. Cancer, 40, 2136-2151.

Lie-Injo, L. E., Caldwell, J., Ganesan, S., and Ganesan, J. (1976). Radioimmunoassay of serum alpha-fetoprotein in patients with different malignant tumors. Cancer, 38, 341-345.

Mason, D. Y., and Taylor, C. R. (1978). Distribution of transferrin, ferritin and lactoferrin in human tissues. Journal of Clinical Pathology, 31, 316-327.
Masopust, J., Kithier, K., Rádl, J., Koutecký, J., and Kotál, L. (1968). Occurrence of fetoprotein in patients with neoplasms and non-neoplastic diseases. International Journal of Cancer, 3, 364-373.

Mehlman, D. J., Bulkley, B. H., Wiernik, P. H. (1971). Serum alpha ${ }_{1}$-fetoglobulin with gastric and prostatic carcinomas. New England Journal of Medicine, 285, 1060-1061.

Mostofi, F. K., and Price, E. B., Jr. (1973). Tumors of germ cell origin. In Tumors of the Male Genital System, Atlas of Tumor Pathology, edited by H. I. Firminger, Second Series, Fascicle 8, pp. 7-84. Armed Forces Institute of Pathology, Washington, D.C.

Neville, A. M., Grigor, K., and Heyderman, E. (1976). Clinicopathological role of tumour index substances in paediatric neoplasia. Journal of Clinical Pathology, 29, 1026-1032.

Nørgaard-Pedersen, B., Albrechtsen, R., and Teilum, G. (1975). Serum alpha-foetoprotein as a marker for endodermal sinus tumour (yolk sac tumour) or a vitelline component of 'teratocarcinoma'. Acta Pathologica et Microbiologica Scandinavica, 83A, 573-589.

Palmer, P. E., Safaii, H., and Wolfe, H. J. (1976). Alpha $_{1}$-antitrypsin and alpha-fetoprotein. Protein markers in endodermal sinus (yolk sac) tumors. American Journal of Clinical Pathology, 65, 575-582.

Palmer, P. E., and Wolfe, H. J. (1978). Immunocytochemical localization of oncodevelopmental proteins in human germ cell and hepatic tumours. Journal of Histochemistry and Cytochemistry, 26, 523-531.

Parkinson, C., and Beilby, J. O. W. (1977). Features of prognostic significance in testicular germ cell tumours. Journal of Clinical Pathology, 30, 113-119.

Pierce, G. B., Bullock, W. K., and Huntington, R. W. Jr. (1970). Yolk sac tumors of the testis. Cancer, 25, 644-658.

Pugh, R. C. B. (1976). Testicular tumours-Introduction. In Pathology of the Testis, edited by R. C. B. Pugh, pp. 139-159. Blackwell Scientific Publications, Oxford.

Pugh, R. C. B., and Cameron, K. M. (1976). Teratoma. In Pathology of the Testis, edited by R. C. B. Pugh, pp. 199-243. Blackwell Scientific Publications, Oxford.

Smith, J. B., and O'Neill, R. T. (1971). a-foetoprotein: occurrence in germinal cell and liver malignancies. American Journal of Medicine, 51, 767-771.

Talerman, A. (1975). The incidence of yolk sac tumor (endodermal sinus tumor) elements in germ cell tumors of the testis in adults. Cancer, 36, 211-215.

Talerman, A., and Haije, W. G. (1974). Alpha-fetoprotein and germ cell tumors: a possible role of yolk sac tumor in production of alpha-fetoprotein. Cancer, 34, 1722-1726.

Talerman, A., Haije, W. G., and Baggerman, L. (1978). Serum alphafetoprotein (AFP) in diagnosis and management of endodermal sinus (yolk sac) tumor and mixed germ cell tumor of the ovary. Cancer, 41, 272-278.

Teilum, G., Albrechtsen, R., and Nørgaard-Pedersen, B. (1975). The histogenetic-embryologic basis for reappearance of alpha-fetoprotein in endodermal sinus tumors (yolk sac tumors) and teratomas. Acta Pathologica et Microbiologica Scandinavica, 83A, 80-86. 
Tsung, S. W. (1975). Alpha-feto protein in lung cancer metastatic to the liver. Archives of Pathology, 99, 267-269.

Tsuchida, Y., Saito, S., Ishida, M., Ohmi, K., Urano, Y., Endo, Y., and Oda, T. (1973). Yolk sac tumor. (Endodermal sinus tumor) and alpha-fetoprotein. Cancer, 32, 917-921.

van Furth, R., and Adinolfi, M. (1969). In vitro synthesis of the foetal $a_{1}$-globulin in man. Nature, 222, 1296-1299.
Wilkinson, E. J., Friedrich, E. G., and Hosty, T. A. (1973). Alpha-fetoprotein and endodermal sinus tumor of the ovary. American Journal of Obstetrics and Gynecology, 116, 711-714.

Requests for reprints to: Dr J. O. W. Beilby, The BlandSutton Institute, The Middlesex Hospital Medical School, London W1, UK. 